\title{
Prevalensi dan Determinan Sindrom Metabolik pada Kelompok Eksekutif di Jakarta dan Sekitarnya
}

\section{Prevalency and Determinant Metabolic Syndrome on Executive Group in Jakarta and Nearby Areas}

\author{
Sudijanto Kamso* Purwantyastuti** Dharmayati Utoyo Lubis*** Ratna Juwita* Yull Kurnia Robbi** Besral*
}

*Fakultas Kesehatan Masyarakat Universitas Indonesia, ***Fakultas Kedokteran Universitas Indonesia, ****Fakultas Psikologi Universitas Indonesia

\begin{abstract}
Abstrak
Data tentang faktor-faktor yang berhubungan dengan sindrom metabolik pada kelompok eksekutif di Indonesia yang diperlukan untuk upaya pencegahan penyakit kardiovaskular sangat terbatas. Penelitian ini bertujuan untuk mengetahui prevalensi dan determinan sindrom metabolik pada kelompok eksekutif. Penelitian dilakukan di Jakarta dan sekitarnya dengan menggunakan rancangan cross sectional. Jumlah responden yaitu 220 orang eksekutif laki-laki dan 68 orang eksekutif wanita. Pengumpulan data dilakukan dengan pengukuran antropometri, analisis biokimia darah, analisis asupan makanan, pengukuran angka stres, dan pengukuran indeks aktivitas. Analisis regresi logistik ganda dilakukan untuk mengetahui hubungan beberapa independen variabel dengan dependen variabel. Analisis ini menghasilkan indeks massa tubuh (overweight, odds ratio (OR) $=5,54$; obesitas, $\mathrm{OR}=7,44$ ) dan rasio total kolesterol/high density lipoprotein ( $\mathrm{HDL})$-kolesterol $(\mathrm{OR}=8,83$ ) sebagai determinan sindrom metabolik pada kelompok eksekutif. Penelitian ini menunjukkan bahwa pemeriksaan profil lipid dan pengukuran antropometri sederhana yang teratur pada kelompok eksekutif penting dilakukan untuk mendeteksi risiko sindrom metabolik.
\end{abstract}

Kata kunci: sindrom metabolik, kelompok eksekutif, antropometri

\footnotetext{
Abstract

Available datas on metabolic syndrome among Indonesian executives are limited, despite the fact of the importance of these data for cardiovaskular prevention. The objective of this study was to assess prevalence of metabolic syndrome and its associations between anthropometric measures, lipid profiles, blood pressure, nutrient intakes, and life style in executive group. A cross sectional study was undertaken in some factories in Jakarta, using multistage random sampling. The respondents were 287 executives, 219 male and 68 female. Data were collected through anthropometric measurements, biochemical blood analysis, nutrient intake, stress score, and activity index assessment. Multiple logistic regression
}

analysis used to assess associations between independent variables and metabolic syndrome. This study showed that body mass index (overweight, odds ratio $(O R)=5,54$; obesity, $O R=7,44$ ) and ratio serum total cholesterol to high density lipoprotein (HDL)-cholesterol $(\mathrm{OR}=8,83$ ) were potential determinants of metabolic syndrome. This study shows the importance of routine check of lipid profile, blood pressure, and simple anthropometric assessment to detect the risk of metabolic syndrome in the elderly.

Key words: metabolic syndrome, executive group, antropometric

\section{Pendahuluan}

Penyakit utama pada kelompok usia dewasa di Indonesia adalah penyakit tulang dan sendi, kardiovaskular, infeksi saluran pernapasan, dan gangguan metabolisme. Data di rumah sakit dan masyarakat menunjukkan penyakit kardiovaskular yang terdiri dari penyakit jantung koroner, penyakit jantung hipertensi, dan stroke adalah penyebab utama kematian pada kelompok usia dewasa. ${ }^{1}$

Sindrom metabolik adalah suatu sindrom yang terdiri dari sekumpulan gejala meliputi peningkatan ukuran lingkar pinggang, peningkatan kadar trigliserida darah, penurunan kadar high density lipoprotein (HDL)kolesterol darah, tekanan darah tinggi, dan intoleransi glukosa. World Health Organization (WHO) menyatakan bahwa seorang individu yang mempunyai 3 dari 5 gejala tersebut sudah dapat dinyatakan menderita sindrom metabolik. Prevalensi sindrom metabolik di Amerika Serikat mencapai 25\%.2 Di Indonesia, pada

Alamat Korespondensi: Sudijanto Kamso, Departemen Biostatistik dan Kependudukan Gedung A Lantai 2 FKM UI Kampus Baru UI Depok 16424, Hp.0816814438, e-mail: sudijantokamso@yahoo.com 
kelompok lanjut usia, prevalensi sindrom metabolik sebesar $14,9 \% .{ }^{3}$ Kriteria sindrom metabolik berdasarkan National Cholesterol Education Program yang dimodifikasi untuk kawasan Asia menyatakan bahwa seseorang dinyatakan menderita sindrom metabolik bila mempunyai 3 dari 5 keadaan seperti peningkatan ukuran lingkar pinggang (>90 cm untuk laki-laki dan $>80 \mathrm{~cm}$ untuk wanita), peningkatan kadar trigliserida darah (> $150 \mathrm{mg} / \mathrm{dl}$ ), kadar HDL kolesterol yang rendah (lakilaki $<45 \mathrm{mg} / \mathrm{dl}$ dan wanita $<50 \mathrm{mg} / \mathrm{dl}$ ), tekanan darah tinggi ( $\geq 130 / \geq 85 \mathrm{~mm} \mathrm{Hg}$ ), dan kadar gula darah puasa $>110 \mathrm{mg} / \mathrm{dl}) .4$

Dengan peningkatan umur terjadi perubahan komposisi tubuh meliputi peningkatan massa lemak, penurunan massa bebas lemak serta penurunan massa tulang. Secara epidemiologi, perubahan komposisi tubuh tersebut, khususnya peningkatan proporsi dan distribusi lemak tubuh akan menyebabkan terjadinya peningkatan akumulasi lemak sentral di abdomen yang mengakibatkan obesitas abdominal atau obesitas sentral. ${ }^{5}$ Metode paling sederhana dan sering digunakan dalam skrining untuk menetapkan obesitas sentral adalah pemeriksaan antropometri lingkar pinggang ( $\mathrm{LiPi}$ ) yang secara klinis dianggap praktis dan valid. ${ }^{6}$

Populasi Asia umumnya dan Indonesia khususnya, mempunyai bentuk tubuh lebih kecil dari populasi Kaukasia. Hal tersebut berisiko obesitas abdominal lebih tinggi dengan indeks massa tubuh (IMT) lebih kecil tetapi LiPi yang lebih tinggi. ${ }^{7}$ Berbagai penelitian menunjukkan bahwa faktor lain yang menyebabkan penyakit kardiovaskular adalah gangguan kadar lemak dalam darah (dislipidemia). Gangguan tersebut dapat berupa peningkatan kadar total kolesterol atau hiperkolesterolemia, penurunan kadar HDL, peningkatan kadar low density lipoprotein (LDL) atau peningkatan kadar trigliserida dalam darah (hipertrigliserida) ${ }^{8}$

Faktor risiko sindrom metabolik adalah psikososial stres melalui mekanisme gangguan keseimbangan hormon hypothalamic-pituitary-adrenal axis (HPAaxis). ${ }^{9}$ Peningkatan lemak di daerah visceral pada penderita obesitas sentral akan meningkatkan risiko resistensi insulin. ${ }^{10-14}$ Aktivitas fisik yang kurang memadai dan asupan kalori yang berlebihan juga merupakan faktor risiko sindrom metabolik. Individu dengan aktivitas fisik yang rendah berisiko menderita sindrom metabolik 2 kali lebih besar daripada mereka yang mempunyai aktivitas fisik yang baik. 15,16 Penelitian di Kanada menunjukkan odds ratio (OR) aktivitas fisik yang baik untuk sindrom metabolik adalah 0,73 (95\% CI $=0,54-0,98$; nilai $\mathrm{p}<0,05)$ dibandingkan aktivitas fisik yang kurang baik. ${ }^{17}$ Penelitian di Inggris menunjukkan bahwa aktivitas fisik pada tingkatan sedang dan tinggi mengurangi risiko mendapatkan sindrom metabolik dengan OR untuk aktivitas fisik sedang adalah 0,78 $(95 \% \mathrm{CI}=0,63 ; 0,96)$ dan untuk aktivitas tinggi adalah $0,52(95 \% \mathrm{CI}=0,40 ; 0,67) \cdot{ }^{16,17}$ Beberapa asupan makanan yang merupakan determinan sindrom metabolik adalah asam lemak jenuh, asam lemak tak jenuh, serat, dan karbohidrat. ${ }^{18}$

Kelompok eksekutif usia produktif pada saat ini ditengarai mempunyai beban pekerjaan yang tinggi, aktivitas fisik yang kurang memadai, dan pola makan yang cenderung tinggi kadar karbohidrat dan lemak sehingga berisiko untuk menderita penyakit kardiovaskular pada usia yang relatif masih muda. Melalui studi ini diharapkan dapat diketahui prevalensi dan determinan dari faktor-faktor yang berhubungan dengan sindrom metabolik pada kelompok eksekutif usia produktif sehingga upaya pencegahan penyakit kardiovaskular dapat dilakukan secara lebih efektif dan rasional.

\section{Metode}

Desain studi yang digunakan dalam penelitian ini adalah potong lintang (cross sectional) dengan melakukan pemeriksaan berbagai faktor yang berhubungan dengan sindrom metabolik pada semua responden. Populasi penelitian berusia antara 25-60 tahun dengan kriteria tampak sehat. Responden berasal dari kelompok eksekutif beberapa perusahaan yang ada dalam masyarakat di Jakarta dan sekitarnya. Kelompok eksekutif adalah mereka yang berada pada level manajerial. Jumlah sampel adalah 300 responden yang ditarik dengan prosedur multistage random sampling dengan perkiraan design effect $=1,5$. Responden dilakukan pengambilan sampel darah puasa dan analisis biokimia dilakukan di Laboratorium Fakultas Kedokteran Universitas Indonesia. Pengukuran antropometri dan tekanan darah dilakukan sesuai dengan prosedur standar yang berlaku sebanyak 2 kali dan analisis selanjutnya diambil nilai rata-rata. Variabel dependen pada penelitian ini adalah lingkar pinggang, HDLkolesterol, trigliserida, kadar gula darah, tekanan darah sistolik, dan tekanan darah diastolik. Variabel independen adalah indeks aktivitas, skala stres, indeks massa tubuh, total kolesterol, LDL-kolesterol, asupan kalori, dan lemak makanan. Kovariat adalah umur, jenis kelamin, dan status merokok. Metode dietary 24-hour recall digunakan untuk mengestimasi asupan makanan dan dianalisis dengan program Nutri-Survey. Aktivitas fisik diukur dengan modifikasi Rapid Assessment of Physical Activity.

Perbedaan nilai rata-rata aktivitas fisik, indeks massa tubuh, asupan kalori, asupan lemak, dan stres antara kelompok sindrom metabolik dan nonsindrom metabolik yang terdistribusi normal diuji dengan T-test (variabel dengan distribusi normal) dan yang tidak 
Tabel 1. Hasil Analisis Bivariat Karakteristik Demografi, Gaya Hidup, dan Sindrom Metabolik

\begin{tabular}{|c|c|c|c|c|c|c|}
\hline \multirow{2}{*}{ Variabel } & \multirow{2}{*}{ Kategori } & \multicolumn{2}{|c|}{ Sindrom Metabolik } & \multirow{2}{*}{ OR } & \multirow{2}{*}{$95 \% \mathrm{CI}$} & \multirow{2}{*}{ Nilai $p$} \\
\hline & & Ya & Tidak & & & \\
\hline \multirow[t]{2}{*}{ Umur (tahun) } & $20-49$ & $150(77,3 \%)$ & $44(22,7 \%)$ & Reference & $0,49-1,68$ & 0,09 \\
\hline & $\geq 50$ & $68(79,1 \%)$ & $18(20,9 \%)$ & 0,91 & & \\
\hline \multirow[t]{3}{*}{ Pendidikan } & SMA/D3 & $26(86,7 \%)$ & $4(13,3 \%)$ & Reference & $0,66-6,2$ & 0,22 \\
\hline & S1 & $106(76,3 \%)$ & $33(23,7 \%)$ & 2,02 & & \\
\hline & S2 & $87(77,7 \%)$ & $25(22,3 \%)$ & 1,87 & & \\
\hline \multirow[t]{2}{*}{ Jenis kelamin } & Laki-laki & $165(75,3 \%)$ & $54(24,7 \%)$ & Reference & $0,60-5,86$ & 0,28 \\
\hline & Wanita & $60(88,2 \%)$ & $8(11,8 \%)$ & 0,44 & & \\
\hline \multirow[t]{2}{*}{ Merokok } & Tidak & $174(79,5 \%)$ & $45(20,5 \%)$ & Reference & $0,19-0,96$ & 0,04 \\
\hline & Ya & $44(72,1 \%)$ & $17(27,9 \%)$ & 1,49 & & \\
\hline \multirow{2}{*}{ Aktivitas fisik } & Aktif & $94(72,3 \%)$ & $36(27,7 \%)$ & Reference & $0,78-2,86$ & 0,23 \\
\hline & Kurang aktif & $131(83,4 \%)$ & $26(16,6 \%)$ & 0,52 & & \\
\hline \multirow[t]{2}{*}{ Stres } & Rendah & $177(79,01 \%)$ & $47(21,0 \%)$ & Reference & $0,29-0,92$ & 0,02 \\
\hline & Sedang & $44(74,6 \%)$ & $15(25,4 \%)$ & 1,28 & $0,66-2,50$ & 0,58 \\
\hline
\end{tabular}

Tabel 2. Prevalensi Komponen Sindrom Metabolik dan Risiko Mempunyai Sindrom Metabolik

\begin{tabular}{|c|c|c|c|c|c|c|}
\hline Komponen Sindrom Metabolik & Prevalensi & Nonsindrom Metabolik & Metabolik Sindrom & OR & $\mathbf{9 5} \% \mathbf{C I}$ & Nilai $p$ \\
\hline Lingkar pinggang tinggi & $58,4 \%$ & $36,3 \%$ & $22,1 \%$ & 1,61 & $1,43-1,81$ & 0,000 \\
\hline Intoleransi glukosa & $11,2 \%$ & $7,0 \%$ & $4,2 \%$ & 2,44 & $1,12-5,34$ & 0,004 \\
\hline Peningkatan trigliserida & $31,5 \%$ & $9,8 \%$ & $21,7 \%$ & 3,21 & $2,36-4,37$ & 0,000 \\
\hline HDL kolesterol rendah & $91,4 \%$ & $69,3 \%$ & $22,1 \%$ & 1,32 & $1,21-1,41$ & 0,01 \\
\hline Hipertensi & $23,3 \%$ & $18,6 \%$ & $4,7 \%$ & 0,865 & $0,84-1,12$ & 0,81 \\
\hline
\end{tabular}

terdistribusi normal diuji dengan metode nonparametrik. Analisis regresi logistik berganda digunakan untuk menganalisis faktor risiko yang dominan terhadap sindrom metabolik dengan dikontrol oleh jenis kelamin, umur, dan status merokok. Uji chi square digunakan sebagai uji hubungan bivariat dan skrining untuk analisis regresi logistik berganda.

\section{Hasil}

Penelitian ini menunjukkan bahwa secara umum prevalensi sindrom metabolik tergolong tinggi $(21,6 \%)$. Prevalensi sindrom metabolik pada eksekutif pria $(24,7 \%)$ lebih tinggi dibandingkan eksekutif wanita $(11,8 \%)$. Analisis bivariat terlihat bahwa karakteristik demografi, gaya hidup, jenis kelamin, dan aktivitas fisik berhubungan dengan sindrom metabolik dengan OR masing-masing $=0,44(95 \% \mathrm{CI}=0,19-0,96$ dan 0,52 $(95 \% \mathrm{CI}=0,29-0,92)$. Sementara variabel demografi, umur, tingkat pendidikan, status merokok, dan stres tidak berhubungan dengan sindrom metabolik (Lihat Tabel 1).

Berdasarkan komponen sindrom metabolik didapatkan bahwa eksekutif dengan obesitas sentral sekitar 22,1\% mempunyai sindrom metabolik. Eksekutif dengan intoleransi glukosa, peningkatan kadar trigliserida, kadar HDL-kolesterol yang rendah, dan hipertensi masing-masing mempunyai $4,2 \%, 21,7 \%, 22,1 \%$, dan $4,7 \%$ sindrom metabolik. Eksekutif dengan kadar trigliserida $>150 \mathrm{mg} / \mathrm{dl}$ mempunyai OR tertinggi yaitu $3,21(95 \% \mathrm{CI}=2,36-4,37)$ (Lihat Tabel 2).

Hasil penelitian menunjukkan bahwa gambaran profil lipid dan antropometri kelompok eksekutif yang menderita sindrom metabolik secara umum kurang baik jika dibandingkan dengan kelompok nonsindrom metabolik. Eksekutif dengan sindrom metabolik mempunyai nilai rata-rata kadar total kolesterol $(202,56$ $\mathrm{mg} / \mathrm{dl}$ vs $187,03 \mathrm{mg} / \mathrm{dl})$, LDL-kolesterol $(139,77 \mathrm{mg} / \mathrm{dl}$ vs $120,77 \mathrm{mg} / \mathrm{dl}$ ) yang lebih tinggi (nilai $\mathrm{p}<0,05$ ), rasio total/HDL-kolesterol $(8,18$ vs 6,3$)$, dan lingkar pinggang $(94,88 \mathrm{~cm}$ vs $87,28 \mathrm{~cm})$. HDL-kolesterol dan IMT kelompok dengan sindrom metabolik menunjukkan nilai rata-rata kadar yang lebih rendah (nilai $\mathrm{p}<0,05$ ) masingmasing $26,67 \mathrm{mg} / \mathrm{dl}$ vs $33,08 \mathrm{mg} / \mathrm{dl}$ dan $27,48 \mathrm{~kg} / \mathrm{m}^{2}$ vs $29.01 \mathrm{~kg} / \mathrm{m}^{2}$. Tidak ada perbedaan yang signifikan pada tekanan darah diastolik, tekanan darah sistolik, asupan energi, asupan lemak, asupan serat, nilai stres serta aktivitas fisik antara eksekutif dengan dan tanpa sindrom metabolik (Lihat Tabel 3).

Analisis regresi logistik menunjukkan hubungan sindrom metabolik dengan IMT dan rasio total kolesterol/HDL-kolesterol. Eksekutif yang overweight mempunyai risiko 5,54 kali lebih besar untuk mengalami 
Tabel 3. Perbandingan Faktor Risiko Para Eksekutif dengan dan tanpa Sindrom Metabolik

\begin{tabular}{lccc}
\hline Faktor Risiko & NonSindrom Metabolik & Sindrom Metabolik & Nilai p \\
\hline Total cholesterol $(\mathrm{mg} / \mathrm{dl})$ & 187,03 & 202,56 & $0,001^{\mathrm{a}}$ \\
LDL- cholesterol (mg/dl) & 120,77 & 139,77 & $0,000^{\mathrm{a}}$ \\
HDL- cholesterol (mg/dl) & 33,08 & 26,67 & $0,000^{\mathrm{a}}$ \\
Trigliserida (mg/dl) & 145,06 & 210,29 & $0,000^{\mathrm{b}}$ \\
Rasio total/HDL kolesterol & 6,3 & 8,18 & $0,000^{\mathrm{b}}$ \\
Indeks massa tubuh (kg/m $\left.{ }^{2}\right)$ & 29,01 & 27,48 & $0,000^{\mathrm{b}}$ \\
Lingkar pinggang (cm) & 87,28 & 94,88 & $0,000^{\mathrm{a}}$ \\
Tekanan darah diastolik (mmHg) & 77,14 & 77,76 & $0,958^{\mathrm{b}}$ \\
Tekanan darah sistolik (mmHg) & 115,30 & 116,67 & $0,646^{\mathrm{b}}$ \\
Asupan energi (kalori) & 1641,90 & 1645,95 & $0,936^{\mathrm{b}}$ \\
Asupan serat (gr) & 12,75 & 10,98 & $0,056^{\mathrm{b}}$ \\
Aktivitas fisik & 3,08 & 3,37 & $0,182^{\mathrm{b}}$ \\
Angka stres & 24,80 & 24,85 & $0,969^{\mathrm{b}}$ \\
\hline
\end{tabular}

Keterangan :

aIndependent $\mathrm{T}$ Test; ${ }^{\mathrm{b}}$ Mann-Whitney U Test

Tabel 4. Analisis Logistik Regresi Faktor Risiko Sindrom Metabolik Koefisien Dikalangan Eksekutif

\begin{tabular}{llccc}
\hline Variabel & Koefisien & OR & $\mathbf{9 5 \%}$ CI & Nilai $\mathbf{p}$ \\
\hline IMT $\left(25-29,99 \mathrm{~kg} / \mathrm{m}^{2}\right)$ & 1,71 & 5,54 & $(2,60-11,84)$ & 0,000 \\
IMT > 30 kg/m² & 2,01 & 7,44 & $(2,48-22,30)$ & 0,000 \\
Rasio kolesterol total/HDL $>5$ & 2,178 & 8,83 & $(2,60-30,02)$ & 0,000 \\
Konstan & $-4,267$ & & & \\
\hline
\end{tabular}

Keterangan :

Signifikansi model $=0,000$

Ketepatan prediksi $=77,9 \%$

sindrom metabolik dibandingkan dengan IMT normal. Eksekutif dengan obesitas berisiko menderita sindrom metabolik 7,44 kali lebih besar dibandingkan dengan IMT normal. Eksekutif yang mempunyai rasio kolesterol total/HDL $\geq 5$ berisiko sindrom metabolik 8,83 kali lebih tinggi dibandingkan dengan rasio $<5$ (Lihat Tabel 4).

\section{Pembahasan}

Berbagai studi tentang penyakit kardiovaskular sering memunculkan pertanyaan mengenai faktor utama yang menyebabkan sindrom metabolik. Interaksi antara asupan makanan dengan sindrom metabolik telah banyak dibahas pada berbagai penelitian, namun masih banyak pertanyaan yang diajukan, apakah ada faktor lain yang mungkin lebih kuat dibandingkan asupan makanan sebagai penyebab sindrom metabolik pada kelompok dewasa dan eksekutif. ${ }^{19}$ WHO Scientific Group melaporkan bahwa faktor nutrisi dan nonnutrisi seperti aktivitas fisik, alkohol, dan stres dapat menjadi faktor risiko sindrom metabolik. Oleh sebab itu, perhatian harus diberikan pada berbagai faktor risiko sindrom metabolik yang penting dan tidak terkonsentrasi pada satu faktor tertentu.
Studi ini menunjukkan bahwa prevalensi sindrom metabolik di kalangan eksekutif adalah $21,6 \%$, dengan prevalensi pada eksekutif pria $(24,7 \%)$ lebih tinggi dibandingkan dengan eksekutif wanita $(11,8 \%)$. Prevalensi sindrom metabolik pada studi ini berbeda dengan studi lain di negara Asia. Hal tersebut diduga karena perbedaan kriteria untuk menentukan sindrom metabolik. Daerah urban Korea, prevalensi sindrom metabolik pada penduduk dewasa berusia 30-80 tahun yaitu laki-laki $(16,0 \%)$ lebih tinggi daripada wanita $(10,7 \%){ }^{20}$

Kriteria hipertensi The National Cholesterol Education Program Adult Treatment Planner III (NCEP ATP) sebagai salah satu komponen sindrom metabolik adalah tekanan darah sistolik $\geq 130 \mathrm{mmHg}$ dan atau tekanan darah diastolik $\geq 85 \mathrm{mmHg}$. Kriteria tersebut memberikan keuntungan karena besaran masalah dapat dideteksi lebih dini sehingga akan berdampak pada program penanggulangan hipertensi dan sindrom metabolik berbasis kesehatan masyarakat yang lebih baik.

Konsekuensi asupan makanan yang berlebih adalah obesitas yang merupakan faktor risiko penyakit lain, 
seperti noninsulin dependen diabetes melitus, penyakit kardiovaskular, dan hipertensi. Ada hubungan positif antara sindrom metabolik dengan parameter obesitas meliputi IMT dan jumlah perlemakan dibawah kulit (sum of skin-folds). Dilaporkan bahwa IMT, suatu indeks dari general obesity, berkorelasi positif dengan tekanan darah sistolik dan diastolik. Kenaikan nilai IMT akan menimbulkan masalah kesehatan. ${ }^{21}$ Penelitian ini menemukan bahwa eksekutif overweight berisiko mengalami sindrom metabolik 5,54 kali lebih tinggi dibandingkan dengan eksekutif yang memiliki IMT normal dan eksekutif yang mengalami obesitas berisiko mengalami metabolik sindrom 7,44 kali lebih tinggi daripada yang normal. Studi Framingham melaporkan bahwa obesitas, baik general maupun central adalah determinan utama hipertensi pada populasi. 22,23

Analisis regresi logistik memperlihatkan hubungan yang kuat antara IMT dan rasio total/HDl-kolesterol dengan sindrom metabolik. Hubungan yang kuat antara hiperkolesterolemia sebagai faktor risiko penyakit kardiovaskular pada usia dewasa menunjukkan bahwa pengobatan untuk menurunkan kadar kolesterol harus digunakan untuk mencegah dan menurunkan angka morbiditas dan mortalitas. Risiko untuk mempunyai penyakit kardiovaskular menjadi 2 kali lebih tinggi pada individu dengan kadar kolesterol $250 \mathrm{mg} / \mathrm{dl} .{ }^{24}$ Penelitian ini menunjukkan bahwa eksekutif dengan rasio total kolesterol/HDL-kolesterol $>5$ berisiko mengalami sindrom metabolik 8,8 kali lebih besar daripada rasio total kolesterol/HDL-kolesterol $<5$.

Kombinasi hipertensi dengan gangguan metabolik dan kelainan kadar lemak darah berhubungan dengan prognosis dan pengobatan. Semakin banyak kombinasi antara komponen sindrom metabolik, semakin serius risiko penyakit kardiovaskular. ${ }^{25}$ Eksekutif dengan 2 atau lebih kombinasi komponen sindrom metabolik yang ditemukan cukup tinggi pada penelitian ini berisiko untuk menderita penyakit kardiovaskular. ${ }^{25}$ Implikasi kesehatan masyarakat dari masalah ini adalah pengembangan program untuk mendeteksi komponen sindrom metabolik pada kalangan eksekutif merupakan upaya yang sangat penting.

\section{Kesimpulan}

Masih banyak hal yang harus dipelajari mengenai sindrom metabolik. Kenyataan bahwa prevalensi sindrom metabolik cukup tinggi, khususnya pada kalangan eksekutif menunjukkan bahwa sindrom metabolik adalah masalah kesehatan masyarakat yang penting. Studi ini menunjukkan bahwa IMT dan rasio total kolesterol terhadap HDL-kolesterol merupakan faktor risiko sindrom metabolik. Hal ini menggambarkan bahwa pemeriksaan reguler kadar lemak darah dan IMT sebagai parameter obesitas sangat penting dilakukan oleh masyarakat pada umumnya dan kalangan eksekutif pada khususnya.

\section{Saran}

Kalangan industri sudah selayaknya memberikan perhatian yang lebih serius tentang peningkatan kesehatan dan kebugaran para karyawannya dengan melakukan pemeriksaan lemak darah, gula darah, tekanan darah secara teratur, yang disertai juga dengan monitoring asupan makanan dan kegiatan peningkatan fisik/olahraga, khususnya kelompok eksekutif perusahaan sebagai motor dunia industri.

\section{Daftar Pustaka}

1. Boedhi DR. Penelitian penyakit kardiovaskular di masyarakat pedesaan. Medika. 1996; 6: 450-7.

2. Ford ES, Giles. Prevalence of metabolic syndrome among US adults: findings from the third national health and nutrition examination survey. JAMA. 2002; 287 (3): 356-9.

3. Kamso S. Metabolic syndrome in the Indonesian elderly. Medical Journal of Indonesia. 2007; 16 (3).

4. National Cholesterol Education Program criteria modified for Asians (NCEP ATP III) Expert Panel on Detection, Evaluation, and Treatment of High Blood Cholesterol in Adults. Executive Summary of the Third Report of the National Cholesterol Education Program (NCEP) Expert Panel on Detection, Evaluation, and Treatment of High Blood Cholesterol in Adults (Adult Treatment Panel III). JAMA. 2001; 285: 2486-97.

5. Guo S. Aging, body composition, and life style: the fels longitudinal study. American Journal of Clinical Nutrition. 1999; 70 (3): 405-11.

6. Turcato. Waist circumference and abdominal sagittal diameter as surrogates of body fat distribution in the elderly: their relation with cardiovascular risk factors. International Journal of Obesity. 2000; 24: 1005-10.

7. Kathryn. Abdominal adiposity and coronary heart disease in women. JAMA. 1998; 280: 1843-8.

8. Marmot MG. Epidemiology of tryglicerides and coronary heart disease. Lancet. 1995; 342: 781-2.

9. Tsigos C. Hypothalamic pituitary adrenal axis, neuroendocrine factors, and stress. J. Psychosom Res. 2002; 53 (4): 865-71.

10. Lara-Castro C, Fu Y, Chung BH, Garvey WT. Adiponectin and the metabolic syndrome: mechanisms mediating risk for metabolic and cardiovascular disease. Curr. Opin. Lipidol. 2007; 18 (3): 263-70.

11. Carr MC. Abdominal obesity and dyslipidemia in the metabolic syndrome: importance of type 2 diabetes and familial combined hyperlipidemia in coronary artery disease risk. J. Clin. Endocrinol. Metab. 2004; 89 (6): 2601-7.

12. Huang. Obesity in the elderly and its relationship with cardiovascular risk factors in Taiwan. Obesity. 2005;13 (1): 170-8.

13. Shen. Waist circumference correlates with metabolic syndrome indicators better than percentage fat. Obesity. 2006; 14 (4): 727-36.

14. Kannel WB. Risk stratification in hypertension: new insights from the framingham study. Am J Hypertens. 2000; 13: 3S-8S. 
15. Katzmaryk. Targeting the metabolic syndrome with exercise: evidence from the heritage family study. Med. Sci. Sports Exerc. 2003; 35 (10): 1703-9.

16. Rennie KL. Association of the metabolic syndrome with both vigorous and moderate physical activity. International Journal of Epidemiology. 2003; 32: 600-6.

17. Susan EB. Physical activity and the metabolic syndrome in Canada. Appl. Physiol. Nutr. Metab. 2006; 31: 40-7.

18. Andrea RJ. Nutritional determinants of metabolic syndrome. J. Nutrigenet Nutrigenomics. 2008; 1: 109-17.

19. Magdalena SR, Mai-Lis BH, De Faire UH, Gunnar KJ. Associations between diet and the metabolic syndrome vary with the validity of dietary intake data. American Journal of Clinical Nutrition. 2003; 78 (1): 84-90.

20. Jee YO, Young SH, Yeon AS, Elizabeth BC. Prevalence and factor analysis of metabolic syndrome in an urban Korean population. Diabetes Care. 2004; 27: 2027-32.

21. Siani A, Cappuccio FP, Barba G, Trevisan M, Farinaro E, Lacone R, et al. The relationship of waist circumference to blood pressure: the olivetti heart study. Am J Hypertens. 2002;15 (9): 780-6.

22. Kannel WB. Fifty years of framingham study contribution to understanding hypertension. J Hum Hypertens. 2000;14: 83-90.

23. Kannel WB. Risk stratification in hypertension: new insights from the framingham study. Am J Hypertens. 2000; 13: 3S-8S.

24. Weverling R, Blauw GJ, Lagaay AM, Knook DL, Meinders AE, Westendorp RGJ. Total cholesterol and risk of mortality in the oldest old. N. Engl. J. Med. 1997; 350: 1119-23.

25. Philip TJ. The obesity epidemic, metabolic syndrome, and future prevention strategies. European Journal of Cardiovascular Prevention and Rehabilitation. 2004. 